\title{
A review of echinoderms from Pleistocene marine deposits near Saint John, New Brunswick
}

\author{
Randall F. Miller and Donald F. McAlpine \\ Natural Sciences Division, New Brunswick Museum, 277 Douglas Avenue, \\ Saint John, New Brunswick E2K 1E5, Canada
}

Date Received April 5, 1991

Date Accepted August 28, 1991

\begin{abstract}
Two species of echinoderm, the brittlestar Ophiura sarsii Lütken and the common green sea urchin Strongylocentrotus droebachiensis Müller, are found in Pleistocene marine clays near Saint John. Today, both of these echinoderms are considered boreal species and both range from the Arctic to somewhat south of Cape Cod. The species have been known to occur as fossils in the Saint John area since before 1865; however, few specimens actually exist. A summary of specimens in the New Brunswick Museum collections is presented, including brittlestars that probably belong to collections referred to by Sir J.W. Dawson. Two sea urchin specimens, not previously documented, are the only fossil specimens known to exist from this area.
\end{abstract}

Deux espèces d'échinoderme se rencontrent au sein des argiles marines pléistocènes aux environs de Saint-Jean: l'ophiure Ophiura sarsii Lütken et l'oursin vert commun Strongylocentrotus droebachiensis Müller. De nos jours, ces échinodermes sont tous deux considérés comme des espèces boréales et leur aire d'occupation s'étend depuis l'Arctique jusqu'à dépasser quelque peu le sud de Cape Cod. La connaissance à l'état fossile de ces espèces dans la région de Saint-Jean date d'avant 1865; cependant, l'inventaire se réduit à quelques spécimens. On donne un aperçu des spécimens dans les collections du Musée du Nouveau-Brunswick, y compris d'ophiures appartenant probablement aux collections auxquelles Sir J.W. Dawson faisait référence. Deux spécimens d'oursin, qui n'ont fait l'objet d'aucune publication jusqu'à ce jour, constituent les seuls exemplaires fossiles connus pour provenir de cette région.

[Traduit par le journal]

\section{INTRODUCTION}

Pleistocene marine invertebrates occur commonly in marine sediments that skirt the southern shoreline of New Brunswick near Saint John (Fig. 1). One of the best exposures occurs at Sheldon Point in west Saint John (Rampton et al., 1984) where mollusc shell dates range from 10,500 to 13,900 years B.P. (Walton et al., 1961; Lowden and Blake, 1970; Gadd, 1973; Rampton et al., 1984; Nicks, 1988). Marine fossils recently discovered in collections of the old Natural History Society of New Brunswick (1862-1932) include specimens of brittlestars, possibly some of the specimens referred to by Sir William Dawson. Dawson (1893) made mention of a brittlestar, Ophioglypha sarsii, from Leda clay near Saint John. Specimens of sea urchin from southern New Brunswick are also documented here.

The purpose of this paper is to summarize and update the literature pertaining to the Pleistocene invertebrate fauna of New Brunswick. Specimens are in the New Brunswick Museum palaeontology collection (NBMG).

Among the earliest observations of Quaternary marine invertebrates were those by Abraham Gesner during his geological survey of New Brunswick (Gesner, 1840, 1841) in which he noted shells, including Mya, Pecten and Mytilus, from clays found in the Saint John region. Although Gesner included an echinoderm, "Clypeaster", from Tertiary marl near St. Andrews in his museum (Gesner, 1842) no specimen has been located. Gesner's contemporary, Robert Foulis (Wright and Miller, 1990) donated a fossil "starfish", collected in the south end of Saint John, to the Boston Society of Natural History in 1855 (Donations, Accession Book, Volume 1, Boston Society of Natural History, "Additions to the Cabinet 1855") where he was a Corresponding Member.

The first comprehensive list of Quaternary invertebrate fossils, including both sea urchins and brittlestars, was complied by Charles Hartt and published in Loring Bailey's Observations on the Geology of Southern New Brunswick (Hartt, 1865). Subsequent references to fossil echinoderms in New Brunswick are listed in Table 1.

\section{Material and Description}

Quaternary clays near Saint John form thick red deposits interbedded with sandy layers (Gadd, 1973; Rampton et al., 1984). Sea urchin and brittlestar specimens are found encased in red clay. Brittlestars are sometimes found in associa- 


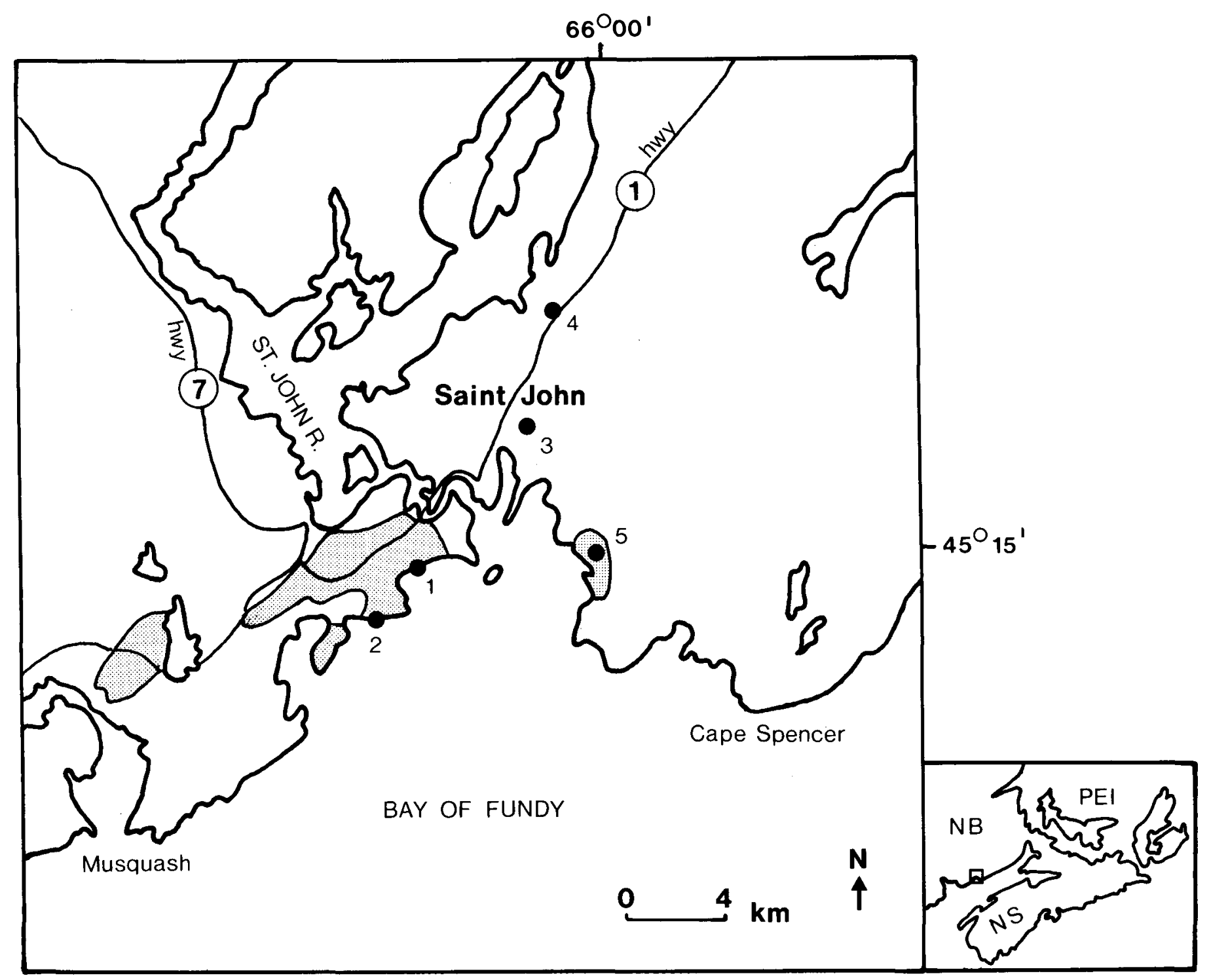

Fig. 1. Quaternary marine sediments exposed near Saint John, New Brunswick; 1. Sheldon Point; 2. Duck Cove; 3. Fernhill Cemetery; 4. Lawlors Lake; 5 . Red Head.

tion with mollusc shells and other traces of organic remains. Sea urchin specimens consist of disarticulated remains, while brittlestars are commonly articulated.

Specimens described here include collections made around, or before, the turn of the century and collections made since 1988 (Table 2). Most of the older specimens were part of holdings of the Natural History Society of New Brunswick (1862 to 1932). George F. Matthew, (1837-1923) the Society's first curator (Miller and Buhay, 1988), published papers on his Quaternary work summarizing the marine fossils (Matthew, 1878, 1879, 1883) from the Saint John area including both brittlestars and sea urchins. Specimens from this pre-1880 period have not been positively identified since Matthew lost much of his early collections in the Great Saint John Fire of 1877 (Miller, 1988).

Geoffrey Stead (1872-1943), a district engineer in New Brunswick, was an active fossil collector and a correspond- ing member of the Society. His Quaternary collections include brittlestar specimens, although collection dates are unknown. Stead did donate "fossil shells and snails" (NHS of NB, Bull No. 8, p. 121) to the Society's museum in 1888 and to the present museum in 1936. In addition to the brittlestar, Stead's collection contains molluscs, Mytilus edulis, Buccinum undatum, Natica clausa, Hiatella arctica, Mya truncata, and Portlandia arctica from the Saint John area.

\section{Sea Urchins}

Two fossil specimens of sea urchin are known from the Saint John area. NBMG 4246 was collected from "Leda Clay", at the Fernhill Cemetery by J.P. Clayton, superintendent of the cemetery between 1898 and 1934. No record has been found for the specimen's acquisition, however in 1904 (NHS of NB, Bull. No. 22, p. 288-89; No. 23, p. 385) and 
Table 1. Summary of references to Quaternary echinoderm fossils in New Brunswick.

\begin{tabular}{|c|c|c|}
\hline Year & Reference & Occurrence \\
\hline 1865 & Hartt, p. 144 & $\begin{array}{l}\text { ophiurans, two species, Duck Cove, Saint John } \\
\text { Toxopneustes drobachiensis (Echinus granulatus), Red Head and } \\
\text { Lawlors Lake, Saint John }\end{array}$ \\
\hline 1875 & Paisley, p. 270 & Strongylocentrotus (Euryechinus) drobachiensis, near Bathurst \\
\hline 1878 & Matthew, p. 111,113 & Ophioglypha sarsii, Duck Cove, Saint John \\
\hline 1879 & Matthew, p. 24EE & $\begin{array}{l}\text { Ophioglypha sarsii, larger ophiuran species, Duck Cove, } \\
\text { Saint John }\end{array}$ \\
\hline 1893 & 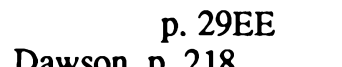 & $\begin{array}{l}\text { Ophioglypha sarsii, Leda clay, near Saint John } \\
\text { Ophioglypha sarsii. Leda clay, near Saint John }\end{array}$ \\
\hline 1973 & Gadd, p. 17 & ophiuroid brittlestar, Sheldon Point, Saint John \\
\hline 1973 & Thomas et al., p. 1330 & Strongylocentrotus drobachiensis, Trou du Docteur, Shippegan \\
\hline
\end{tabular}

Table 2. Quaternary echinoderm specimens, New Brunswick Museum.

$\begin{array}{ll}\text { Species } & \text { Catalogue No. }\end{array}$

$\begin{array}{lc}\text { Strongylocentrotus droebachiensis } & \text { NBMG 4246, 4640 } \\ \text { Ophiura sarsii } & \text { NBMG 4007, 4561, 4575, 4576, 4578, 6014, 8349, 8350, 8440 } \\ \text { Ophiura cf. } \text { O. sarsii } & \text { NBMG 4560, 4577, 4622, 4623, 4624, 4625, 4626, 4627, 6015, } \\ & 8347,8348\end{array}$

again in 1909-10, Clayton donated "Leda clay containing fossil mussels" (NHS of NB, Bull. No. 28, p. 279) to the Society. In a letter accompanying the 1904 donation Clayton noted the elevation at about 115 feet $(35 \mathrm{~m})$ above high water in Marsh Creek, although a city official reported the elevation at 95 feet $(29 \mathrm{~m})$ above high tide (NHS of NB, Bull. No. 22, p. 289). NBMG 4640 was found near Quaco, east of Saint John (collector and date unknown). No other information accompanies the specimen although mollusc collections were made in the area by Stead.

Specimens are composed of disarticulated ambulacral and interambulacral plates and spines (Fig. 2a-e) and in specimen NBMG 4246 there are fragments of the lantern, including at least two teeth and pyramid. Two species of sea urchin, the common green urchin (Strongylocentrotus droebachiensis) and the purple urchin (Arbacia punctulata) occur along the northeast coast of North America today. $S$. droebachiensis ranges from Cape Cod to the Arctic while $A$. punctulata occurs from Cape Cod south to the Caribbean. The fossil specimens were identified as Strongylocentrotus droebachiensis, probably by Matthew or Stead and this determination is confirmed based on the arrangement of tubercules and pores on the plates (Gosner, 1979).

\section{Brittlestars}

More than twenty brittlestar specimens from Saint John are represented in the NBM collection (Fig. 3a, b). Although only eleven have locality data, all specimens were probably collected from Sheldon Point and Duck Cove (Fig. 1). They are generally preserved as partial or split specimens consisting of the interior of the oral or aboral side of the specimen. Specimens often display a well-preserved central disk clearly presenting the interior mouth, radiating arms and spines. The largest central disk diameter measures about $12 \mathrm{~mm}$. Gosner (1971) described eleven ophiurids that occur along the northeast coast of North America today. The fossils are variously preserved but nine are identifiable as $O$ phiura sarsii based on the keys of Gosner (1971), which include disk diameter and characteristics of the spines as criteria. Less well-preserved specimens probably belong to the same species (Table 2).

Specimen NBMG 4007/2 consists of a partial disk with arms lying across a pelecypod shell fragment (Fig. 3b), probably Mya sp. Specimens recently collected by A.A. Seaman (DNRE, Fredericton) and one of us (RFM) were found about $18-20 \mathrm{~m}$ above sea level at Sheldon Point in clay with alternating silt and sand laminae, about 1 to $2 \mathrm{~m}$ below the overlying pebble gravel. NBMG 6015 was found in a 


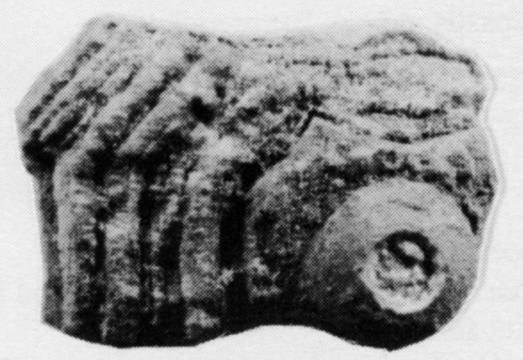

a

b

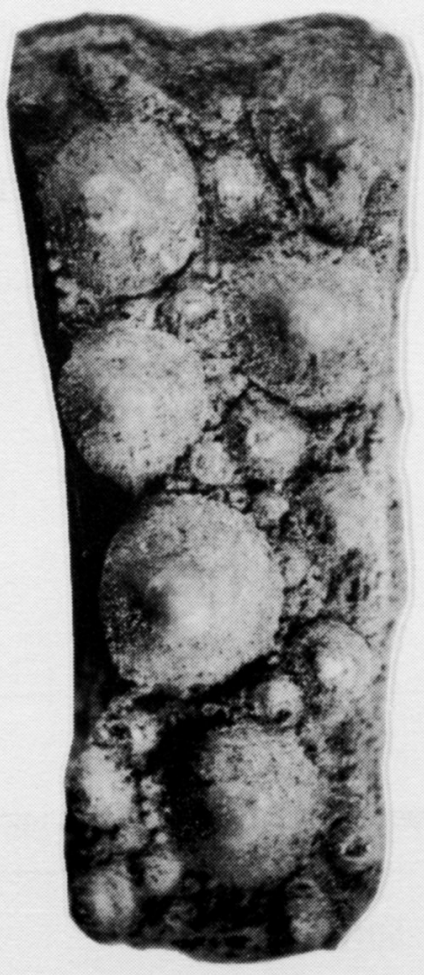

e

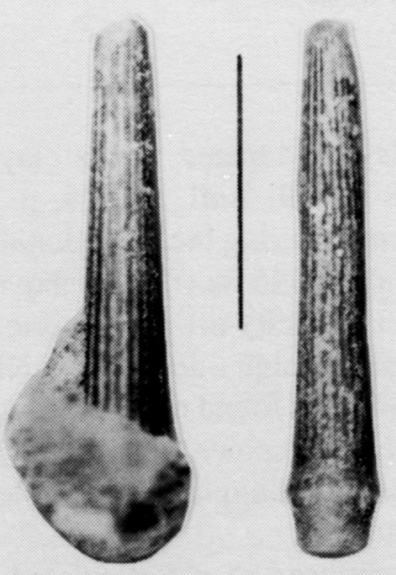

Fig. 2. Strongylocentrotus droebachiensis, Fernhill Cemetery, Saint John, NBMG 4246. (a) inter ambulacral plate, (b) ambulacral plate, (c) lantern tooth, (d) lantern pyramid fragment, (e) spines. Scale bar $=2 \mathrm{~mm}$.

slump block at the east end of Sheldon Point just above the high tide level in association with Portlandia arctica, a mollusc which has been identified in zones dated from about $11,500-14,000$ years B.P. (Nicks, 1988). Hartt (1865) and Matthew (1879) listed a second, larger ophiuran species in association with $O$. sarsii however no other species have been recovered from the Natural History Society of New Brunswick collections or observed in recent collections.

\section{Ecology and Distribution}

The distribution and ecological preferences of both Strongylocentrotus droebachiensis and Ophiura sarsii are generally known. Potential economic importance of $S$. droebachiensis for a sea urchin roe industry has resulted in numerous studies of its ecology. Both species have wide environmental tolerances and therefore limited use as paleoclimatic indica- 


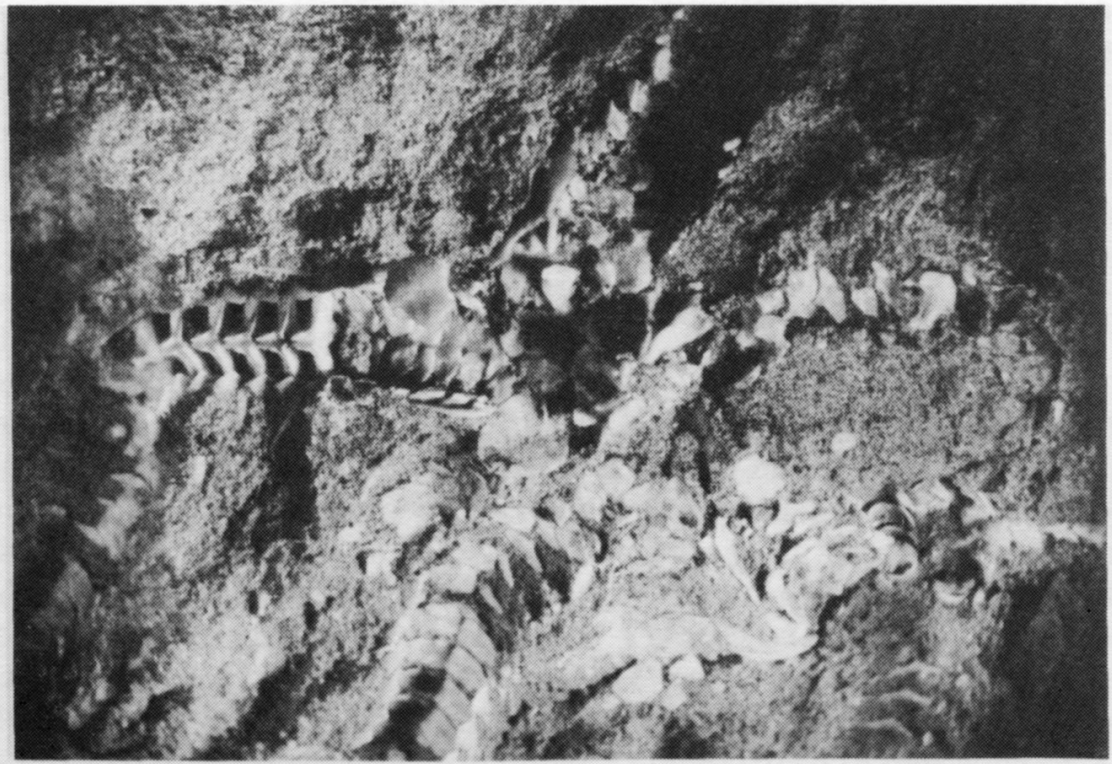

a

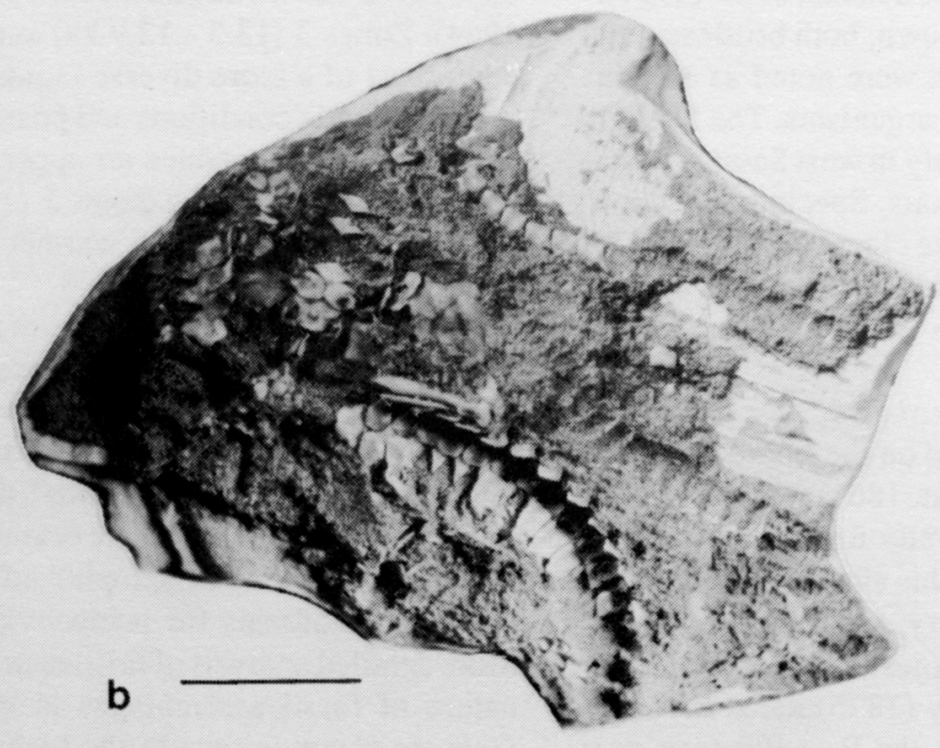

Fig. 3. Ophiura sarsii, Duck Cove, Saint John. (a) NBMG 4007/1, (b) NBMG 4007/2. Scale bar $=5 \mathrm{~mm}$.

tors. However, an understanding of their habits may provide some useful information about paleoecology.

$S$. droebachiensis is a widely distributed, euryhaline echinoderm. Its range is circumpolar, extending into boreal regions of both the northern Atlantic and Pacific Oceans (Mortensen, 1943). In the western Atlantic it occurs in the high Arctic. In many areas it is one the most common subtidal benthic animals. It can be found from intertidal pools to depths of almost $1000 \mathrm{~m}$ (Miller and Bishop, 1973). In the Bay of Fundy it occurs to depths of $18 \mathrm{~m}$ (MacKay, 1976). S. droebachiensis feeds on a wide variety of non-calcareous algae such as Laminaria and is preyed upon by lobsters, crabs, starfish, birds and fish (Himmelman and Steele, 1971). Laboratory studies have determined that $10^{\circ} \mathrm{C}$ is the upper limit for larval growth and that the distribution of $S$. droebachiensis correlates well with this experimental value. It is found in seas where temperature during the spring rarely exceed $6-8^{\circ} \mathrm{C}$. The adult may be exposed to summer temperatures $5-10^{\circ} \mathrm{C}$ warmer (Stephens, 1972). Larvae survive temperatures below $0^{\circ} \mathrm{C}$, allowing Stephens to suggest that the northern limit in distribution is determined by freezing, permitting circumpolar distribution.

$O$. sarsii can be found on mud bottoms from the intertidal zone to depths of about $3000 \mathrm{~m}$. It is commonly reported from depths of 70-140 m. It has a circumpolar geographic distribution. In the North Atlantic it has been reported from Norway and Greenland and as far south as Georgia on the east coast of North America. Thorson (1971) described typical Ophiura 
sarsii communities in waters near Denmark. In the sublittoral zone $O$. sarsii was associated with bivalves, amphipods, acorn worms, sea mouse and bristle worms. Assemblages in deeper water communities, below $200 \mathrm{~m}$, included shrimp, sea pen, bristle worms and bivalves. Brittle stars can be very numerous often lying so densely that their arms can search every square metre of the bottom every 24 hours.

\section{Discussion}

Pleistocene echinoderm fossils have been described from a number of localities in Champlain Sea deposits in Quebec and Ontario such as Green's Creek, near Ottawa (Harington, 1983) where they occur in marine clays in association with molluscs and other invertebrates, fish, seal remains and plants. Similar fossils have been found in marine clay deposits near Saint John. Unfortunately many Quaternary specimens have been lost leaving brief references as the only evidence of their occurrence. Harington and Occhietti (1988) and Miller (1990) have reviewed the fossil marine mammal fauna from New Brunswick. A summary of Pleistocene marine invertebrates can be found in Seaman et al. (1991).

Although few specimens are known, both brittlestar and sea urchin remains from Saint John were noted as early as 1865 (Hartt, 1865) along with other organisms. The Sheldon Point - Duck Cove - Sand Cove locality in west Saint John has been the principal source of brittlestars. Specimens occur in black sand layers between red marine clays (Matthew, 1879; Gadd, 1973). Matthew (1878, p.111) referred to "starfish beds at Duck Cove" in discussions of Ophiura sarsii and associated species.

Strongylocentrotus droebachiensis was described from the "Leda" clay in a section exposed on the Intercontinental Railway line at Lawlor's Lake (Hartt, 1865) where Matthew worked on both marine and freshwater deposits (Matthew, 1883). Matthew's specimens from this site are unknown but the specimen from Fernhill Cemetery, collected by Clayton was likely identified by Matthew suggesting his earlier determinations were also correct. Paisley (1875) listed Euryechinus drobachiensis as occurring in the Post-Pliocene near Bathurst. Dawson (1893) summarized the Canadian "Ice Age" fauna and referred to Ophioglypha sarsii from Saint John. However, even though he mentioned occurrences of $S$. droebachiensis in Quebec, he did not refer to its Saint John locality. The most recent description of Pleistocene echinoderm remains from New Brunswick are from a shell deposit near Shippegan (Thomas et al., 1973). Among the fauna dominated largely by pelecypods and gastropods, Strongylocentrotus droebachiensis (NBMG 8537) was identified as common component of the assemblage.

The marine fossil assemblage as described from Sheldon Point (Gadd, 1973) suggests a near-shore intertidal environment. Nicks (1988) described the deposit as a glaciomarine end moraine, a time transgressive sequence $(14,000$ to 10,000 years B.P.) from a tidewater glacier to subaerial exposure. Molluscs include a number of "cold" water species like Hiatella arctica, Macoma baltica, and Portlandia arctica
(Gadd, 1973). Most of the marine mollusc species found in late glacial deposits near Saint John can be described as boreal species ranging from the Bay of Fundy south to Cape Cod (Gosner, 1979). Gadd (1973) noted the lack of warmer water species such as oysters, scallops and sea urchins in the fauna. In the same paper results presented from ostracod analysis suggested very cold, shallow water. The modern distribution of $S$. droebachiensis along with its environmental preferences suggest that it could inhabit the colder waters of a deglaciated Bay of Fundy. Postglacial sea-surface temperatures near Saint John, postulated by Bousfield and Thomas (1975) from littoral marine invertebrate distributions, are less than $12^{\circ} \mathrm{C}$ at 12,500 years B.P.

The age of the sea urchin and brittlestar fossils from Saint John is unknown. Recent dating of molluscs has demonstrated a range of ages within the marine deposits. Eight "mollusc zones" were recognized by Nicks (1988) for the late glacial deposits of New Brunswick and Maine. Zone 2, the oldest fossil-bearing zone ( 14.0 - $13.5 \mathrm{ka})$, was characterized by Hiatella arctica and Portlandia arctica. Hiatella produced carbon-14 dates ranging from $13100 \pm 160$ (GSC 3557 ) to $13900 \pm 620$ (GSC 3354) years B.P. (Rampton et al., 1984). Zones $3(13.5-12.9 \mathrm{ka})$ and $4(12.9-12.5 \mathrm{ka})$ were comprised of a more diverse fauna suggesting an amelioration in climatic conditions and possibly a stratification of the water column to produce an upper less saline horizon with salinity as low as $5 \%$. Zone $5(12.5-12.1 \mathrm{ka})$ contained molluscs that suggest still warmer conditions and a lack of year round sea-ice cover.

Reliable stratigraphic information for Ophiura sarsii and Strongylocentrotus droebachiensis is lacking making it difficult to correlate the distribution of these species with the more abundant mollusc fauna or to place their occurrence into any of the "mollusc zones" defined by Nicks (1988). Improved awareness of their occurrence in marine deposits will result in better stratigraphic information and perhaps the use of echinoderms for paleoenvironmental interpretation. More detailed analysis of brittlestar beds might determine the nature of fossil assemblages in comparison with modern Ophiura communities. In the bathyl zone around Japan for example, disc diameter size-frequency distribution has been compared with depth demonstrating that larger individuals are found at greater depths (Fujita and Ohta, 1990). The limited sample set discussed here would suggest shallower water based on a preliminary comparison with data presented in the study near Japan.

S. droebachiensis has certainly received little attention even though a number of records of its occurrence are known. Smith (1984) reviewed preservation of echinoids and suggested a correlation between the state of preservation and the manner of death. NBMG 4246 resembles Smith's description of a "Localised pile of dissociated plates, spines and lantern elements" that suggest death in a tranquil environment, not related to storm action. Observations on better documented specimens may provide added information to paleoenvironmental interpretations. 


\section{ACKNOWLEDGEMENTS}

The authors wish to thank those who have added to the NBM collection, S. Bedell, K. Jarvis, K. Saunders, and A. Seaman. Transfer of material from UNB was co-ordinated by, R.K. Pickerill and J. Noble. A. Logan made specimens from Shippegan available from the UNBSJ paleontology collection.

Bousfield, E.L. and Thомas, M.L.H. 1975. Postglacial changes in distribution of littoral marine invertebrates in the Canadian Atlantic Region. Proceedings of the Nova Scotia Institute of Science, 27, Supplement 3, pp. 47-60.

Dawson, J.W. 1893. The Canadian Ice Age. W.V. Dawson, Montreal, $301 \mathrm{p}$.

Fujita, T. and Онта, S. 1990. Size structure of dense populations of the brittle star Ophiura sarsii (Ophiuroidea: Echinodermata) in the bathyl zone around Japan. Marine Ecology, Progress Series 64, pp. 113-122.

GADD, N.R. 1973. Quaternary Geology of southwest New Brunswick with particular reference to Fredericton area. Geological Survey of Canada, Paper 71-34, 31 p.

Gesner, A. 1840. Second Report on the Geological Survey of the Province of New Brunswick. Henry Chubb, Saint John, 76 p. 1841. Third Report on the Geological Survey of the Province of New Brunswick. Henry Chubb, Saint John, 88 p.

- 1842. Synopsis of the Contents of Gesner's Museum of Natural History at Saint John, N.B. Henry Chubb, Saint John, $48 \mathrm{p}$.

GosNER, K.L. 1971. Guide to the Identification of Marine and Estuarine Invertebrates. Wiley-Interscience, New York, 693 p.

1979. A Field Guide to the Atlantic Seashore. The Peterson Field Guide Series. Houghton Mifflin, Boston, 329 p.

Harinoton, C.R. 1983. Significance of the fossil locality at Green Creek, Ontario. Trail and Landscape, 17, pp. 164-178.

Harington, C.R. and OcchietTh, S. 1988. Inventaire systématique et paléoécologie des mammifères marins de la Mer de Champlain (fin du Wisconsinien) et de ses voires d'accès. Géographie Physique et Quaternaire, 42, pp. 45-64.

HartT, C.F. 1865. List of New Brunswick Fossils. In Observations on the Geology of Southern New Brunswick, Appendix B. Edited by L.W. Bailey. G.E. Fenety, Printer, Fredericton, pp. 143-147.

Himmelman, J.H. and Steele, D.H. 1971. Foods and predators of the green sea urchin Strongylocentrotus droebachiensis in Newfoundland waters. Marine Biology, 9, pp. 315-322.

Lowden, J.A. and BlaKe, W., JR. 1970. Geological Survey of Canada radiocarbon dates IX. Geological Survey of Canada, Paper 70-2, Part B, 86 p.

MacKay, A. 1976. The Sea Urchin Roe Industry. Marine Research Associates, Deer Island, New Brunswick, 92 p.
Matthew, G.F. 1878. On the Mollusca of the Post-Pliocene formation in Acadia. Canadian Naturalist, 8, pp. 104-117. - 1879. Report on the surficial geology of southern New Brunswick. Geological Survey of Canada, Report of Progress 1877-78, Pt. EE, pp. 1-36.

1883. Lacustrine formation of the Torryburn Valley. Bulletin of the Natural History Society of New Brunswick, No. 2, pp. 3-20.

MilleR, R.F. 1988. George Frederic Matthew (1837-1923). In Trace fossils, small shelly fossils and the PrecambrianCambrian Boundary, Proceedings. Edited by E. Landing and G.M. Narbonne. New York State Museum, Bulletin 463, pp. 4-7.

Miller, R.F. 1990. New records of postglacial walrus and a review of Quaternary marine mammals in New Brunswick. Atlantic Geology, 26, pp. 97-107.

MilleR, R.F. and Buhay, D.N. 1988. The Steinhammer Club: geology and a foundation for a natural history society in New Brunswick. Geoscience Canada, 15, pp. 221-226.

Miller, R.J. and Bishop, C.A. 1973. A Sea Urchin Fishery for Eastern Canada. Fisheries and Marine Service, Biological Station, St. John's, Newfoundland, Circular 19.

Mortensen, T. 1943. A Monograph of the Echinoidea, Volume III, Part 3. C.A. Reitzel, Copenhagen, 469 p.

Nicks, L.P. 1988. The Study of the Glacial Stratigraphy and Sedimentation of the Sheldon Point Moraine, Saint John, New Brunswick. Unpublished M.Sc. thesis, Dalhousie University, Halifax, Nova Scotia.

PAISLEY, C.H. 1875. On the Post-Pliocene formation near Bathurst, New Brunswick. Canadian Naturalist, 7, pp. 268-270.

Rampton, V.N., Gauthier, R.C., Thibault, J., and Seaman, A.A. 1984. Quaternary Geology of New Brunswick. Geological Survey of Canada, Memoir 416, 77 p.

Seaman, A.A., Broster, B.E, Cwynar, L., Lamothe, M., Miller, R.F., and Thibault, J.J. 1991. Late Glacial and Post-Glacial Events in Coastal Environments, Southwestern New Brunswick. CANQUA 1991 Field Excursion Guide, 107 p.

SмIтн, A.B. 1984. Echinoid palaeobiology. George, Allen and Unwin, London, 190 p.

STEPhens, R.E. 1972. Studies on the development of the sea urchin Strongylocentrotus droebachiensis. 1. Ecology and normal development. Biological Bulletin, 142, pp. 132-144.

Thomas, M.L.H., Grant, D.R., and De GraCe, M. 1973. A Late Pleistocene marine shell deposit at Shippegan, New Brunswick. Canadian Journal of Earth Sciences, 10, pp. 1329. 1332.

Thorson, G. 1971. Life in the Sea. McGraw-Hill, Toronto, 256 p.

Walton, A., Trautman, M.A., and Friend, J.P. 1961. Isotopes Inc., radiocarbon measurements I. American Journal of Science, Radiocarbon Supplement, 3, pp. 47-59.

Wrioht, H.E. and MILLER, R.F. 1990. Robert Foulis (1796-1866): New Brunswick Inventor, Entrepreneur and Geologist. Geoscience Canada, 17, pp. 101-104. 